\title{
EVALUATION OF BIOLOGICAL SAFETY OF MILK ON BIOENERGETIC STATUS OF COWS
}

\section{ОЦЕНКА БИОЛОГИЧЕСКОЙ БЕЗОПАСНОСТИ МОЛОКА ПО БИОЭНЕРГЕТИЧЕСКОМУ СТАТУСУ КОРОВ}

\section{K. Leshukov, Candidate of Biological Sciences}

К.А. Лещуков, кандидат биологических наук

\author{
Y. Krasyuk, Post-graduate student \\ Ю.Ю. Красюк, аспирант
}

\author{
Orel State Agrarian University, Orel City, Russia \\ Орловский государственный аграрный университет, г. Орёл, Россия \\ Phone: +7 (920) 803-50-40, E-mail: kost177@ mail.ru
}

Received May 22, 2012

\begin{abstract}
The obtained data allow to argue about existence of close correlation between the content in milk of somatic cages and existence in it various compound substances. The raised number of somatic cages as the most sensitive indicator, allows to catch changes in a chemical composition of a secret of an udder, that is signals about fall of dairy efficiency. However the increase in number of somatic cages can be caused and other factors, in particular approach of the last stage of pregnancy. It is established that on level of capacity of biologically active centers of cows it is possible to estimate with a high share of probability quantity of somatic cages in milk for the purpose of further technological differentiation of milk raw materials.
\end{abstract}

\section{АННОТАЦИЯ}

Полученные данные позволяют утверждать о наличии тесной корреляции между содержанием в молоке соматических клеток и наличием в нем различных составных веществ. Повышенное число соматических клеток, как самый чувствительный индикатор, позволяет уловить изменения в химическом составе секрета вымени, то есть сигнализирует о понижении молочной продуктивности. Однако увеличение числа соматических клеток может быть вызвано и другими факторами, в частности наступлением последней стадии беременности. Установлено, что по уровню потенциала биологически активных центров коров можно с высокой долей вероятности оченивать количество соматических клеток в молоке с иелью дальнейшей технологической дифференцииации молока-сырья.

\section{KEY WORDS}

Milk; Cows; Biological value; Biosafety.

\section{КЛЮЧЕВЫЕ СЛОВА}

Молоко; Коровы; Биологическая иенность; Биобезопасность.

Молочные заводы постоянно предъявляют фермам и производителям особые требования к качеству молока как исходному сырью для переработки. Основными показателями, характеризующими качество молока, являются: содержание жира, содержание белка, содержание соматических клеток. Если на содержание жира и содержание белка в основном влияют кормление и генетика коров, то содержание соматических клеток - показатель здоровья вымени. В связи с этим в условиях Орловской области, является актуальным разработка достоверных методов оценки 
технологической пригодности молока по физиологическим параметрам животных.

Установлено, что по уровню биоэлектрического потенциала (УБП) биологически активных центров (БАЦ) можно судить о физиологическом состоянии и продуктивности животных (А.М. Гуськов, А.В. Мамаев, 1998, 2005; А.Н. Шепелев, 2001; К.А. Лещуков, 2004).

Опираясь на сегментарную теорию строения и связей вегетативной нервной системы, а также руководствуясь рецептурой применения методов акупунктуры в практике животноводства (Г.В. Казеев,1994) и результатами собственных исследований, было выбрано семь биологически активных центров (БАЦ) коров №1, №3, №16, №20, №38, №39, №44, связанных с молочной продуктивностью и качеством молока-сырья.

Целью наших исследований являлось установить взаимосвязь между количеством соматических клеток в молоке и биоэнергетическим статусом животных, который оценивали по среднему биоэлектрическому потенциалу БАЦ №1,№3,№16,o20,№38,№39,o44. Нумерация центров принята по Казееву Г.В.(1994): №1-локализация: на дорзо-медиальной линии между 1-м и 2-м остистыми отростками грудных позвонков;

№3-локализация: на дорзо-медиальной линии между 11-м и 12-м остистыми отростками грудных позвонков;

№16-локализация: на расстоянии одной ширины ладони от дорзо-медиальной линии тела между 1-м и 2-м поперечными отростками поясничных позвонков;

№20-локализация: на расстоянии одной ширины ладони от дорзо-медиальной линии тела между 5-м и 6-м поперечными отростками поясничных позвонков;

№44-локализация: на 3 поперечника пальца ниже края подколенника, латеральнее на 1 поперечный палец от гребешка большеберцовой кости;

№38-локализация: одна ширина ладони от последнего ребра и одна ширина ладони под поперечными отростками поясничных позвонков;

№39- локализация три ширины ладони от дорзо-медиальной линии тела и две ширины ладони от последнего ребра, примерно на уровне тазобедренного сустава.

Таблица 1 - Взаимосвязь уровня биопотенциала биологически активных центров коров и количества соматических клеток

\begin{tabular}{|c|c|c|c|}
\hline № группы & $\begin{array}{c}\text { Количество живот- } \\
\text { ных, голов }\end{array}$ & $\begin{array}{c}\text { Средний УБП по 7 } \\
\text { БАЦ,мкА }\end{array}$ & $\begin{array}{c}\text { Среднее количество соматических } \\
\text { клеток,тыс.мл }\end{array}$ \\
\hline 1 (1-я лактация, контроль) & 4 & $22,5 \pm 1,17$ & $158000 \pm 3,9$ \\
\hline 2 (2-я лактация) & 4 & $26,5 \pm 1,23^{*}$ & $160000 \pm 1,1$ \\
\hline 3 (3-я лактация) & 4 & $27,9 \pm 1,05^{*}$ & $225000 \pm 9,8^{* *}$ \\
\hline 4 (4-я лактация) & 4 & $31,5 \pm 1,01^{* *}$ & $296000 \pm 7,6^{* * *}$ \\
\hline 5 (5-я лактация) & 4 & $32,8 \pm 0,91^{* *}$ & $380000 \pm 6,8^{* * *}$ \\
\hline
\end{tabular}

Примечание: различия статистически достоверны по сравнению с контролем - * $\mathrm{p}<0.05, * * \mathrm{p}<0.01, * * * \mathrm{p}<0.001$

С возрастом различия в значениях по уровню биопотенциала и количеству соматических клеток проявились более отчетливо.

Результаты проведенных исследований свидетельствуют что, чем старше корова, тем выше содержание соматических клеток в молоке. Однако у коров поздней лактации на фоне роста числа соматических клеток отмечен параллельный рост УБП БАЦ. Так наибольшее число соматических клеток обнаружено у коров пятой лактации - 380000 тыс.мл, а наименьшее в первой лактации - 158000 тыс.мл (при $\mathrm{p}<0,001$ ). Разница составляет 58,5\%. Также установлено, что у коров второй лактации УБП выше по сравнению с контролем на
$15 \%$, а коровы третьей и четвертой лактации превосходили по УБП на 19,3\% (p<0,05) и $28,5 \%(\mathrm{p}<0,01)$ соответственно. Максимальное значение уровня биопотенциала отмечается у животных пятой лактации - 32,8 мкА, а минимальное в первой лактации - 22,5 мкА (при высокодостоверных различиях).

Анализ полученных данных говорит о том, что существует тесная корреляция между содержанием в молоке соматических клеток, наличием в нем различных составных веществ и надоем. Повышенное число соматических клеток, как самый чувствительный индикатор, позволяет уловить изменения в химическом составе секрета вымени, то есть 
сигнализирует о понижении молочной продуктивности. Однако увеличение числа соматических клеток может быть вызвано и другими факторами, в частности наступлением последней стадии беременности. Изменение числа соматических клеток также носит сезонный характер.
Таким образом, установлено, что по уровню биопотенциала БАЦ коров можно с высокой долей вероятности оценивать количество соматических клеток в молоке с целью дальнейшей технологической дифференциации молока-сырья.

\section{БИБЛИОГРАФИЯ}

Jaskowski, J.M. Nectore przyczyny obnizajacej sie plodnosci u krow mlecznych / J.M. Jaskowski, J. Jlechnowicz, W. Nowak // Medycyna Weteiynaryja. 2006. - V. 62. - № 4. - Pp.385-389

Sambraus H.H.; Thaller G.; Kurz S. Liege- und Komfortverhalten von Milchkuhen bei der "Freiheitsanbindung". Schrifl/Kuratorium Techn.Bauwesen in Landwirtsch. -MunsterHiltrup, 2010, №391 - S. 119.
Roche, J.F. Reproductive management of postpartum cows / J.F. Roche, D. Mackey, M.D. Diskin // Anim. Reprod. Sci. 2009, P. 703712.

Westwood, C.T. Factors influencing fertility on Holstein dairy cows: a multivariate description / C.T. Westwood, I.J. Lean, J.K. Karvin // J/ Dairy Sci. 2009. - V.85 - n. 12. Pp.3225-3237. 